\title{
FDG-PET in mantle cell lymphoma involving skin
}

\section{Deri tutulumlu mantle hücreli lenfomada FDG-PET}

\author{
Mehmet Sönmez1, Ümit Çobanoğlu², Savaş Karyağar3, Bircan Sönmez4 \\ 1Department of Hematology, School of Medicine, Karadeniz Technical University, Trabzon, Turkey \\ 2Department of Pathology, School of Medicine, Karadeniz Technical University, Trabzon, Turkey \\ 3Department of Nuclear Medicine, Trabzon Numune Training and Research Hospital, Trabzon, Turkey \\ 4 Department of Nuclear Medicine, School of Medicine, Karadeniz Technical University, Trabzon, Turkey
}

A 61-year-old female patient presents to the hospital with fatigue and weakness. Physical examination was unremarkable except for pallor. White blood cell count (WBC) was $40.500 / \mu \mathrm{L}$ with $62 \%$ blast. Hemoglobin (Hgb) level was 7.4g/dl and platelet (PIt) count was $146.000 / \mu \mathrm{L}$. Bone marrow examination revealed hypercellular marrow and infiltration with blast cells (Figure 1). Blastic cells expressed CD45, CD79a, CD19, CD20, CD5, and cyclin D1 with no expression of CD23. Other laboratory investigations including urea, electrolytes and liver function tests were all in normal limits. No abnormality was detected by computed tomography (CT) scans of neck, thorax, abdomen, and pelvis except splenomegaly $(150 \mathrm{~mm})$. Based on the findings, the diagnosis of blastoid variant of mantle cell lymphoma (MCL) was established. She received the CHOP chemotherapy regimen (Cylophosphamide-Doxorub- icin-Prednisone-Vincristine) combined with rituximab and achieved complete remission. Ten months later, under routine follow-up, multiple reddish nodules on the back and upper extremities, and trunk were observed (Figure 2). Laboratory parameters, bone marrow examination, and CT scans were normal. Skin lesion biopsy revealed MCL (Figure 3).
Fluorodeoxyglucose-positron emission tomography (FDG-PET) scan, which was performed to determine the stage of the skin involvement, showed multiple areas of abnormal uptake in skin (Figure 4).

$\mathrm{MCL}$ commonly involves extranodal sites. Skin involvement occurs in only $2 \%-6 \%$ of all cases of $\mathrm{MCL}$ but is seen in $17 \%$ of stage IV patients. The blastoid types MCL are more aggressive than MCL and associ-

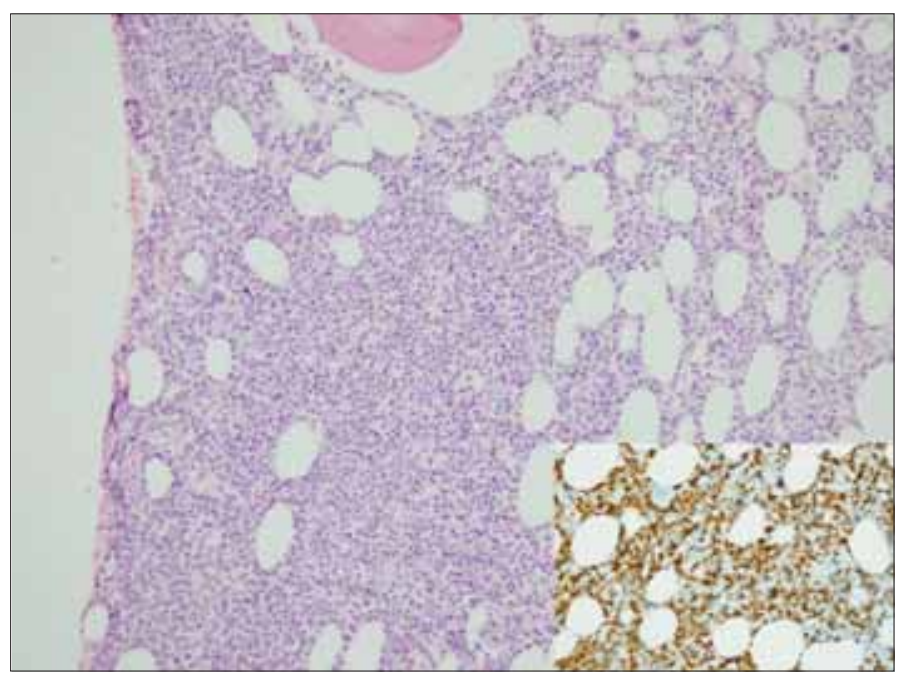

Figure 1. Atypical blastic cell infiltration in the bone marrow biopsy (inset; cyclin D1 positivity) 


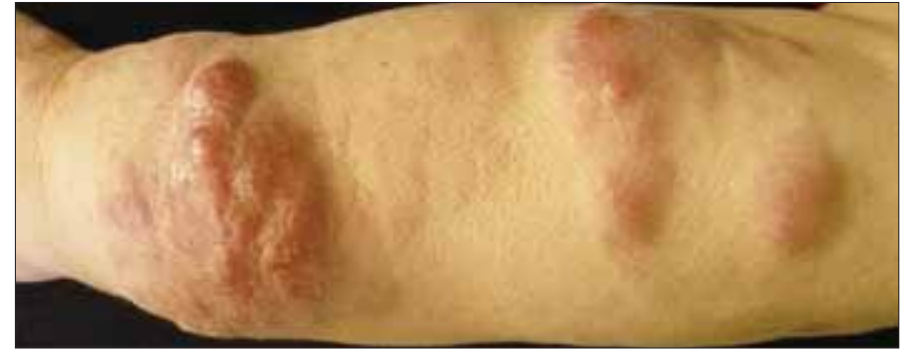

Figure 2. Appearance of reddish nodules on upper extremity

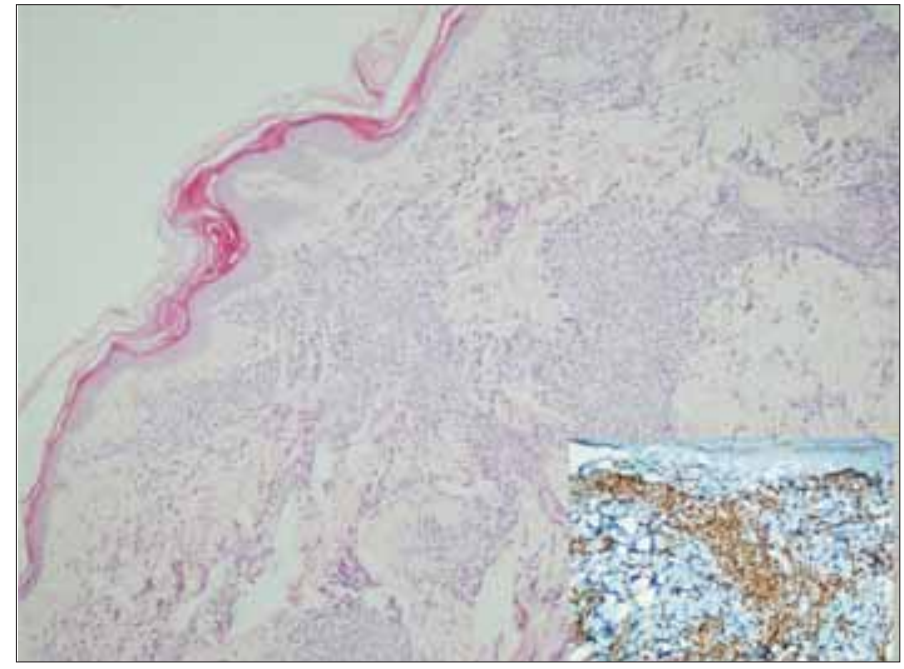

Figure 3. Histopathological appearance of mantle cell lymphoma in the skin biopsy (inset; cyclin D1 positivity)

ated with a worse clinical outcome. Only a few cases with blastoid variant $\mathrm{MCL}$ and skin involvement have been described in English literature. In MCL, FDGPET detects more disease sites, nodal as well as extranodal, than conventional imaging methods, resulting in a higher sensitivity [1-3].

Written informed consent was obtained from the patient.

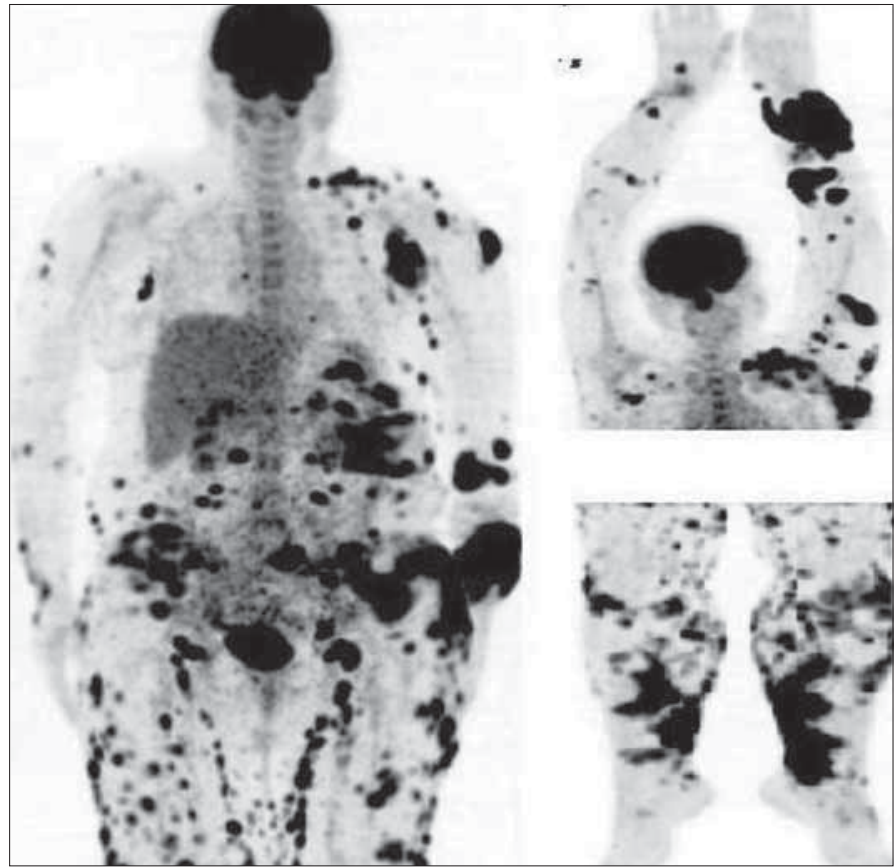

Figure 4. Appearance of multiple abnormal uptake on FDG-PET

\section{Conflict of Interest}

No author of this paper has a conflict of interest, including specific financial interests, relationships, and/or affiliations relevant to the subject matter or materials included in this manuscript.

\section{R eferences}

1. Hutchings $M$, Specht L. PET/CT in the management of haematological malignancies. EurJ Haematol. 2008;80:369-80.

2. Estrozi B, Sanches JA J r, Varela PC, Bacchi CE. Primary cutaneous blastoid mantle cell lymphoma-case report. Am J Dermatopathol. 2009;31:398-400.

3. Motegi S, Okada E, Nagai Y, Tamura A, Ishikawa O. Skin manifestation of mantle cell lymphoma. EurJ Dermatol. 2006;16:435-8. 